\title{
Dam-lake Operation to Optimize Fish Habitat
}

\author{
M. Fayzul K. Pasha ${ }^{1} \cdot$ Dilruba Yeasmin $^{2}$ • \\ Jeremy W. Rentch ${ }^{1}$
}

Received: 22 January 2015 / Accepted: 17 August 2015 / Published online: 27 August 2015

(C) Springer International Publishing Switzerland 2015

\begin{abstract}
The existence of dams cannot be ignored. The dam-lake formed due to the construction of a dam can be considered an integrated part of the natural watershed. A question which must be answered is how to operate a dam-lake so that the negative impacts of the dam on the natural flow system are reduced and at the same time the intended purposes of the dam are efficiently met. Among many aquatic species, the fish species are probably the most highly impacted species by the construction of a dam. As a result of the dam, fish habitat can decrease resulting in low productivity to no productivity at all for some fish species. This paper presents a methodology to develop a dam-lake operation model to maximize fish habitat. This study considered the physical habitat of smallmouth bass in its adult life. The operation model is developed by linking one-dimensional hydraulics model HEC-2 and dam-lake simulation model HEC-5 with a meta-heuristic optimization algorithm, the Shuffled Frog Leaping Algorithm (SFLA). The computation of physical habitat, which is a function of habitat suitability index and some hydraulic parameters, is coded within the optimization algorithm. The model has been successfully applied to an unnamed dam-lake in the northeast of the U.S. The fish habitat for smallmouth bass in its adult life stage increases as the water surface in the dam-lake increases. Some recommendations to improve the model are discussed in the conclusions section.
\end{abstract}

Keywords Fish habitat - Dam-lake operation · Optimization · Hydraulics · Habitat suitability index $\cdot$ Smallmouth bass

M. Fayzul K. Pasha

mpasha@csufresno.edu

1 Department of Civil and Geomatics Engineering, California State University, Fresno; 2320 E. San Ramon Ave. MS/EE94, Fresno, CA 93740, USA

2 California Water Institute, California State University, Fresno, CA 93740, USA 


\section{Introduction}

Dams are important components of modern civilization. Their social and technological benefits are profound. Through the construction of a dam on a river, its water can be managed effectively and efficiently for many primary purposes such as for flood control, hydropower generation, drinking water supply, agricultural water supply, etc. Secondary purposes include recreation, transportation, wildlife and fish habitat management, land development, etc. (Waters et al. 2015; Liu et al. 2014; Piman et al. 2013; Richter and Thomas 2007; Jager and Smith 2008; National Fish Habitat Action Plan 2009).

A dam, which fragments a river, however, may have some adverse impacts on biodiversity and ecosystems. In one instance, the dam-lake operation can manage the river water effectively, however, in other instances, it can put the overall riparian biodiversity in danger. Of all the adverse impacts due to the construction and operation of the dam, the most pervasive one is the effect on the ecosystem (Richter and Thomas 2007; Poff et al. 1997; Postel and Richter 2003). Major ecological impacts due to flow alteration as a result of the dam installation include modified floodplain and channel physical habitats, disruption in aquatic life evolution, disconnection in longitudinal and lateral hydraulic connectivity, and invasion of exotic species (Bunn and Arthington 2002; Richter and Thomas 2007).

Fish is one of the important components of the ecosystem. It not only provides food and recreation for humans, but also maintains a healthy ecological balance in the flora and fauna of riparian habitats. Due to construction and operation of a dam, the natural fluctuations in the stream water are no longer available which reduces the required areas for fish to grow and reproduce, and even to hide from predators (King et al. 2015; Waters et al. 2015; National Fish Habitat Action Plan 2009; Null and Lund 2012; Piman et al. 2013; Jager and Smith 2008; Paragamian et al. 2001).

Certainly the aim of an operation is to maximize the benefits for which it is constructed, for example, to maximize power generation, water supply, flood control, recreation, etc. The balance between a healthy ecosystem and maximization of the intended purposes of a dam sometimes gets little or no importance at all. This is perhaps due to the fact that the interactions between different components of the ecosystem are complex and often the impacts of the dam on the ecosystem are not well understood. For example, different fish species require different water depth, temperature, substrate, and other hydraulic attributes in their different life stages. Maximizing a single objective or an intended purpose may result in little or no importance to the fish habitats for different fish species in their different life stages. Generally, dam-lake operation, which is a cascade in nature, disrupts the ecosystem that can reduce fish habitat. The physical fish habitat of a fish species for a particular life stage can be quantified using certain indices, such as functions of hydraulics and substrates, and thus, the effect of dam-lake operation on fish habitats can be quantified.

Researchers are focusing on how to balance benefits and adverse impacts of a dam. More recently, dam-lake operation, i.e., finding the frequency and magnitude of water release from a dam-lake is being studied more than ever before to find the operational conditions that warrant the full benefits, including ecological and non-ecological benefits, such as hydropower, flood control etc. With modified dam-lake operation policies and scheduling, adverse environmental impacts can be reduced. This paper presents a methodology to optimize dam-lake operation for maximizing the physical habitat of a certain fish species. It is understood that there might be several fish species present in a stream reach and the relationships between their habitats and hydraulics are complex. Therefore, maximizing fish habitat for a certain fish species may not 
be beneficial for other species and even for the same species under different life stages. An integrated study is thus always required for a dam-lake operation. However, the main objective of this study is to develop an operational model, in general, that maximizes fish habitat for certain life stage of a fish species. This model can also be applied to other species for maximizing their physical habitats at different life stages as well.

In this study, a meta-heuristic optimization algorithm, the Shuffled Frog Leaping Algorithm (SFLA) has been coupled with the dam-lake simulation model, HEC-5 (USACE 1998), and open channel hydraulics simulation model, HEC-2 (USACE 1991), to develop the operation model. Smallmouth bass in its adult life stage is considered in this study for maximizing its physical habitat in the upstream of a dam in the northeastern U.S.

\section{Background}

Dam-lake operations disrupt natural flow in the river. Controlled fluctuations in the river flow potentially alter the integrity of the regional ecosystem. For example, in Switzerland hydropeaking affects $30 \%$ of the monitored river ecosystem (Shen and Diplas 2010; FOEN 2013). Hydropeaking can also affect in-stream fish and other species. A reduction in benthic invertebrates and displacement in fry can be observed as a result of hydropeaking (Shen and Diplas 2010; Lauters et al. 1996; Liebig et al. 1999; Orth et al. 2004).

Dam-lake operation can affect the reproduction of different fish species. After the completion of Libby dam on the Kootenai River in 1972, the white sturgeon population became isolated and distinct in the Columbia River basin (McDonald et al. 2010; Paragamian et al. 2001; Setter and Brannon 1990). The white sturgeons in the Kootenai River became listed as an endangered species in 1994 (USFWS 1994). There are a few hypotheses that relate the decline in white sturgeons to the change in river hydraulics and sediment transport. Duke et al. (1999) outlined a hypothesis that describes how Libby Dam might affect the sturgeon spawning.

The fish habitat structures, i.e., trees, shrubs, and other landscape features, may decompose in five to twenty years or may be covered up with silt and sediment (National Fish Habitat Action Plan 2009) resulting in low productivity for fish. An unplanned dam-lake operation can accelerate the cover up rate. The National Fish Habitat Action Plan (2009) grouped the fish habitat challenges that the dam-lakes face into six categories: riparian and shoreline hydrologic conditions, watershed connectivity, water quality, sediment inputs, physical habitat, and nuisance species.

While in some cases the dam-lake can be entirely removed to restore the natural system, in most cases this is not an option due to the fact that the dam-lake has become a permanent component of the basin system. Therefore, it should be operated efficiently and effectively such that the objectives of the reservoir's primary purposes should be maximized while satisfying the secondary and other environmental constraints.

Null and Lund (2012) used an optimization model to assess the tradeoffs between restoration costs and fish production. They used the model to rank restoration alternatives for fish habitat improvement. Temperature and flow, the two habitat parameters that are subject to change with restoration alternatives such as instream flow, riparian shade, diversion, dam removal, and cool-water spring restoration, are considered in 
their study. They applied the methodology to Coho Salmon fish species in California's Shasta River. Null and Lund (2012) mentioned that the tradeoff between restoration costs and fish production can prioritize restoration alternatives.

Shen and Diplas (2010) used a three-dimensional hydrodynamic model to calculate time dependent velocities, water surface elevations, and shear stresses to examine the role of damlake release on juvenile brown trout habitat in the Smith River in Virginia. The results from two dam-lake releases, one being historical and the other being hypothetical, are compared. The hypothetical release can maintain longer refugia and decrease the erosion area by allowing gradual increase in water release.

\section{Model Development}

Fish habitat can be defined as the required aquatic environment, essential for the biological and physical processes of a fish species during their different life stages. Instream hydraulics is one of the important components that affect the aquatic environment. One of the approaches to quantify fish habitat is to relate the instream hydraulics with habitat suitability index (HSI) (Edwards et al. 1983; Raleigh et al. 1986; Simon and Cooper 2014; Heath et al. 2015). The habitat suitability index varies with hydraulics and other physical and environmental factors. A composite suitability criterion (CS) which is calculated from all the habitat suitability indices can be used to quantify the fish habitat. The composite suitability criteria which ranges from 0 to 1 is determined by multiplying all the habitat suitability indices (HSI) for all the parameters together.

A quantity that can be used to describe the spatial habitat area of a specific fish species for a particular life stage is called the weighted usable area (WUA) (Chen et al. 2015; Yao et al. 2014; Payne 2003; Conder and Annear 1987). For a specific cell $i$ in a stream, the weighted usable area (WUA) is defined as the multiplication of the composite suitability criterion $\left(C S_{i}\right)$ for a specific life stage of a fish species, and the surface area $\left(A_{i}\right)$. The total WUA for the entire stream of $n$ cells is the sum of WUA for all the cells in the stream.

$$
W U A_{\text {stream }}=\sum_{i=1}^{n}\left(C S_{i}^{*} A_{i}\right)
$$

Upon the selection of habitat suitability indices (HSI) of a fish species, the instream hydraulics, i.e., flow, velocity, depth, top width, and the length between transects (the verticals where the hydraulics are measured) are measured to calculate WUA. As seen from Eq. (1), the unit of the weighted usable area is in square length $\left(\mathrm{ft}^{2}, \mathrm{mi}^{2}\right.$, or $\mathrm{km}^{2}$ ). In this study, the dam-lake operation model to maximize fish habitat (i.e., WUA) consists of integrating instream hydraulics and habitat suitability indices with dam-lake operation decisions. Mathematically,

$$
\text { Maximize } W U A(k)=\sum_{t=1}^{T} \sum_{i=1}^{n}\left(C S_{i, t} * A_{i, t}(k)\right)
$$


subject to:

$$
\begin{gathered}
G_{H}(H, Q)=0 \\
k_{\text {wlower }} \leq k \leq k_{\text {wupper }}
\end{gathered}
$$

where $C S_{i, t}$ in Eq. (2) is the composite suitability criterion for cell $i$ at time $t$. The composite suitability criterion is calculated as the multiplication of all the habitat suitability indices (HSI) determined for different parameters. $A_{i, t}$ as mentioned in Eq. (1) is the wetted surface area of cell $i$ at time $t$, and is a function of dam-lake operation decisions, $\boldsymbol{k} . \boldsymbol{H}$ and $\boldsymbol{Q}$ are the vectors of water depth and flow at each transect at every time step. $\boldsymbol{G}_{\boldsymbol{H}}$ (Eq. 3) are conservation of energy and mass that describe system's flow distribution, $\boldsymbol{Q}$, and water depth, $\boldsymbol{H}$. $\boldsymbol{k}$ is the dam-lake operation decision which has upper and lower bounds, $k_{\text {wupper }}$ and $k_{\text {wlower }}$, respectively. The operation decision $\boldsymbol{k}$ is a vector of gate configuration. It comprises the number of gates opened or closed in any day for the entire simulation period.

Calculating the system's hydraulics is the central part of this operation model. A onedimensional hydraulic model, HEC-2 (USACE 1991) is used to simulate instream hydraulics. The dam-lake operation model determines the release (outflow) from the lake based upon some set of rules which can depend on inflow, amount of storage in the lake, environmental and ecological needs both upstream and downstream of the dam, and other physical factors. HEC-5 (USACE 1998), a lake simulation model for flood control and conservation systems, is used for this purpose. HEC-5 model is useful to determine the dam-lake release. Hydraulic simulation model HEC-2 and the dam-lake simulation model HEC-5 are linked together with an optimization algorithm, the Shuffled Frog Leaping Algorithm (Eusuff et al. 2006), to develop the operation model. HEC-2 is a computer model that determines the water surface profile for a steady gradually varied flow in a channel. The water surface elevation, velocity, and depth are the outputs of the model (USACE 1991). Although the DOS (Disk Operating System) interface of HEC-2 later upgraded to GUI (Graphical User Interface) and the name of HEC-2 became HECRAS, the basic calculation engine is still the same. The old DOS version can easily be linked with an optimization code and a customized model can easily be developed. SFLA is a meta-heuristic optimization specially designed for combinatorial optimization problems. It is a population-based search technique in which the points in the search space exchange information to improve the objective function (Eusuff et al. 2006). The executable application files of HEC-2 and HEC-5 models are linked with the SFLA optimization algorithm which is written in $\mathrm{C}++$ programming language.

The methodology consists of the following steps. Based on an operation decision, the damlake's storage and water surface elevation are determined at each time step for the inflow into the dam-lake. With the dam-lake's known water surface elevation, the system's hydraulics are calculated using the hydraulic simulation model. The hydraulics information is saved and then used with the habitat suitability indices (e.g., habitat suitability for depth and velocity) to calculate the weighted usable area for the entire reach in the next step. The process continues until the end of the simulation period, i.e., the end of the inflow hydrograph. Weighted usable areas (WUA) are summed over the entire period of simulation to calculate the total WUA for the entire system. At this stage one full system simulation is done. 
The operation decision (i.e., frog in SFLA) controls the dam-lake storage and system's hydraulics. An initial population of frogs, or points (i.e., operational decision), is randomly generated within the specified boundary. The points (frogs) are then evaluated following the procedure mentioned above. The new points (frogs) are generated next, following the optimization procedure and another set of evaluations are completed. This iterative process continues until a stopping criterion is reached. A full description SFLA optimization can be found in Eusuff et al. (2006) and Pasha and Lansey (2009).

\section{Case Study}

The model has been applied to a hypothetical dam-lake (Fig. 1) which was created by slight modifications of an unnamed dam-lake in the northeast U.S. Modification includes changing the sizes of the control gates at the dam. The surface area of the dam-lake is generally about 20.7 sq. $\mathrm{km}(8 \mathrm{sq} . \mathrm{mi})$ with average widths of about $1.61 \mathrm{~km}(1 \mathrm{mile})$ in the downstream and about $0.64 \mathrm{~km}(0.4$ miles $)$ in the upstream. The length of the dam-lake is about $17.7 \mathrm{~km}(11$ miles) along the centerline. The total storage of the dam-lake is about 75,431 ha-m $(611,530 \mathrm{ac}-\mathrm{ft})$. The storage elevation curve of the dam-lake is shown in Fig. 2. The surface area of the dam-lake can vary depending upon the hydrologic, hydraulic, and dam-lake gate operation conditions, i.e., at higher storage the extent of the lake can be larger and vice versa.

A drainage area of 686.3 sq. $\mathrm{km}$ (265 sq. mi) contributes flow into the dam-lake. Historical discharge data (from 1956 to 2010) has been used to calculate the annual, monthly, and peak flow statistics. The mean annual flow from the watershed is $10.5 \mathrm{~m}^{3} / \mathrm{s}(370 \mathrm{cfs})$. The average monthly flow is $11.6 \mathrm{~m}^{3} / \mathrm{s}$ (408 $\mathrm{cfs}$ ) with the maximum and minimum monthly flows of $21.6 \mathrm{~m}^{3} / \mathrm{s}(763 \mathrm{cfs})$ and $5.9 \mathrm{~m}^{3} / \mathrm{s}(209 \mathrm{cfs})$ observed in the months of March and August, respectively. The average yearly peak flow is about $175.6 \mathrm{~m}^{3} / \mathrm{s}(6200 \mathrm{cfs})$ with the maximum and minimum peak flows of $603.1 \mathrm{~m}^{3} / \mathrm{s}(21,300 \mathrm{cfs})$ and $46.4 \mathrm{~m}^{3} / \mathrm{s}(1640 \mathrm{cfs})$, respectively. A 15-day long hydrograph of daily discharge in the month of March is considered as the inflow into the dam-lake (Fig. 3) for this model. The average daily flow of the inflow hydrograph is

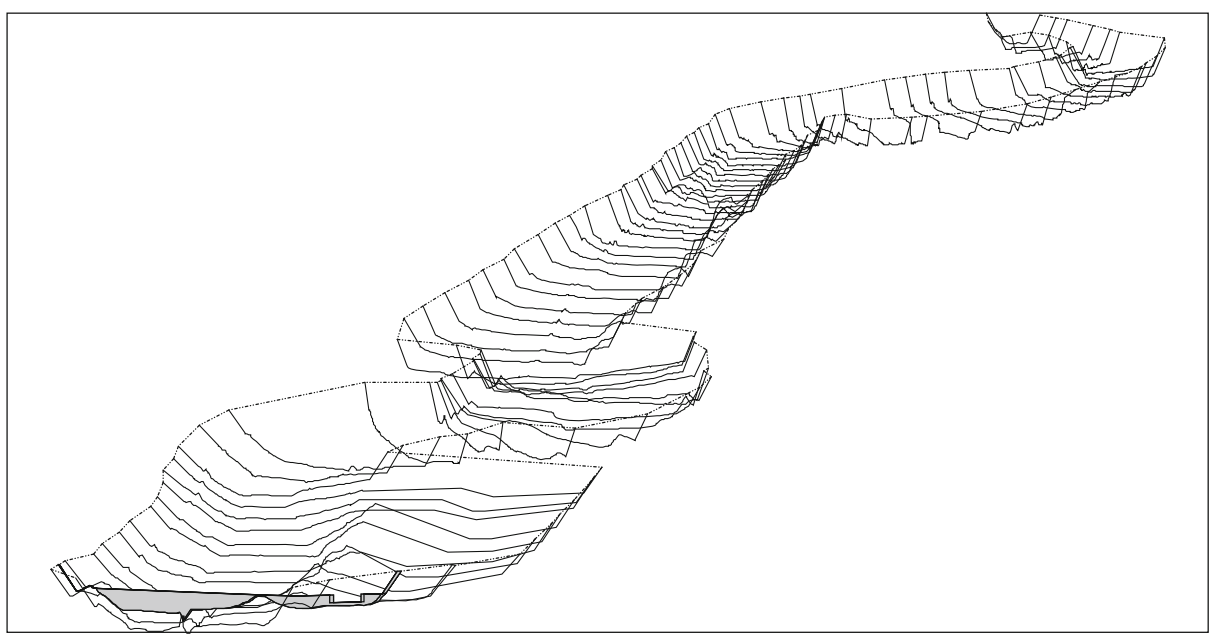

Fig. 1 Application dam-lake 


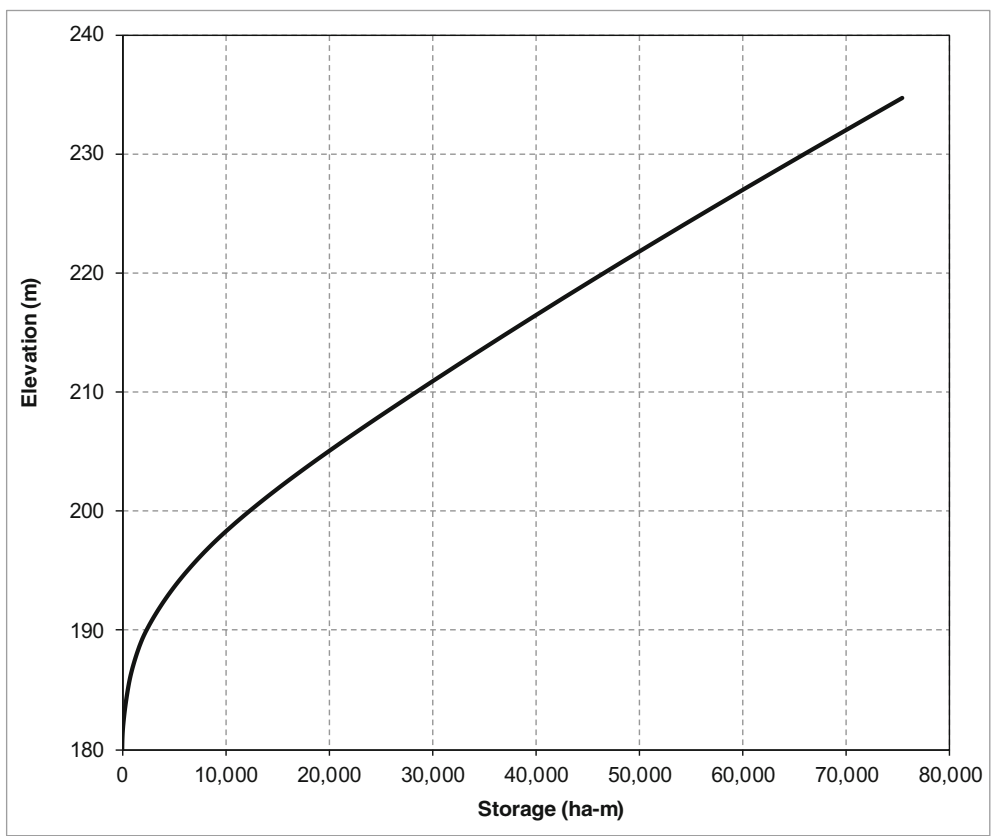

Fig. 2 Storage-elevation curve

$35.3 \mathrm{~m}^{3} / \mathrm{s}(1245 \mathrm{cfs})$ with the maximum and minimum of 128.0 and $12.4 \mathrm{~m}^{3} / \mathrm{s}$ (4520 and 438 cfs), respectively.

One dimensional hydraulics in the stream has been modeled using the HEC-2 (USACE 1991) hydraulics simulation model. A total of 77 cross-sections have been used at an average interval of $228.6 \mathrm{~m} \mathrm{(750} \mathrm{ft)} \mathrm{(Fig.} \mathrm{1).} \mathrm{The} \mathrm{average} \mathrm{channel} \mathrm{slope} \mathrm{in} \mathrm{the} \mathrm{downstream} \mathrm{portion} \mathrm{is}$ about $0.02 \mathrm{~m} / \mathrm{km}(0.1 \mathrm{ft} / \mathrm{mile})$, which increases to an average of about $1.14 \mathrm{~m} / \mathrm{km}(6 \mathrm{ft} / \mathrm{mile})$ in the upstream. Manning $n$, which represents the roughness of the channel due to the amount and

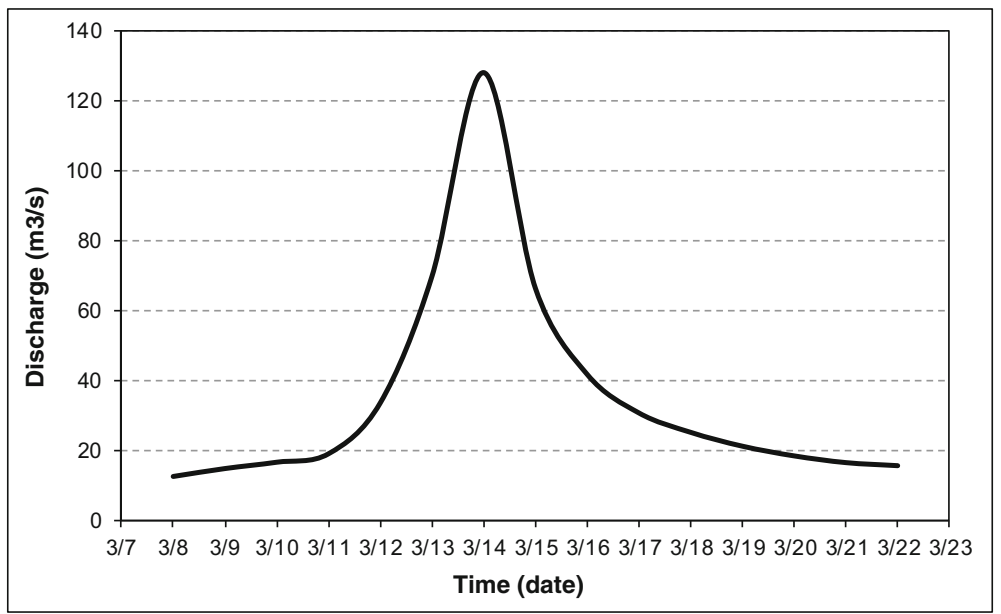

Fig. 3 Inflow Hydrograph 
type of vegetation (USACE 1991) is 0.04 for the main channel and 0.06 to 0.10 for the overbanks.

Three control gates, each being $1.22 \times 2.44 \mathrm{~m}(4 \times 8 \mathrm{ft})$ in size, were used to control the outflow from the dam-lake. As mentioned before, HEC-5 is used as the dam-lake simulation model. The gates are configured such that the opening heights of each of the gate can be at $0.0 \mathrm{~m}(0 \mathrm{ft})$ (closed), $0.91 \mathrm{~m}(3 \mathrm{ft}), 1.52 \mathrm{~m}(5 \mathrm{ft})$, or $2.44 \mathrm{~m}(8 \mathrm{ft})$ (fully opened). Considering three gates together, the total possible combinations of gate openings are 20 (Table 1). While gate configuration 0 represents all the gates closed, gate configuration 19 means all gates opened with highest gate opening heights (i.e., $2.44 \mathrm{~m}$ ) (Table 1). In this study, gate configuration 0 is not considered. Therefore, the total possible gate configurations are 19 for any given day. This gate configuration is the decision variable in the optimization model. On any given day, there are 19 possible combinations (configuration) from which a single combination can be chosen. This chosen combination for that day can affect the decision of configuration selection on the next day. Thus, the total number of possible combinations can be significantly high. If the simulation period is considered to be 15 days, the possible combinations can be as high as $2.2 \times 10^{22}$ from which the optimization model would find the optimal solution. Rating curves related to each gate configuration are used to calculate the outflow discharge from the dam-lake. Therefore, a total of 19 rating curves are used in the optimization model.

Table 1 Possible combination of gate configuration

\begin{tabular}{|c|c|c|c|}
\hline \multirow[t]{2}{*}{ Combination } & \multicolumn{3}{|l|}{ Opening height } \\
\hline & Gate 1 & Gate 2 & Gate 3 \\
\hline 0 & Closed & Closed & Closed \\
\hline 1 & $0.91 \mathrm{~m}(3 \mathrm{ft})$ & Closed & Closed \\
\hline 2 & $0.91 \mathrm{~m}(3 \mathrm{ft})$ & $0.91 \mathrm{~m}(3 \mathrm{ft})$ & Closed \\
\hline 3 & $0.91 \mathrm{~m}(3 \mathrm{ft})$ & $0.91 \mathrm{~m}(3 \mathrm{ft})$ & $0.91 \mathrm{~m}(3 \mathrm{ft})$ \\
\hline 4 & $1.52 \mathrm{~m}(5 \mathrm{ft})$ & Closed & Closed \\
\hline 5 & $1.52 \mathrm{~m}(5 \mathrm{ft})$ & $0.91 \mathrm{~m}(3 \mathrm{ft})$ & Closed \\
\hline 6 & $1.52 \mathrm{~m}(5 \mathrm{ft})$ & $0.91 \mathrm{~m}(3 \mathrm{ft})$ & $0.91 \mathrm{~m}(3 \mathrm{ft})$ \\
\hline 7 & $1.52 \mathrm{~m}(5 \mathrm{ft})$ & $1.52 \mathrm{~m} \mathrm{(5 \textrm {ft } )}$ & Closed \\
\hline 8 & $1.52 \mathrm{~m} \mathrm{(5 \textrm {ft } )}$ & $1.52 \mathrm{~m}(5 \mathrm{ft})$ & $0.91 \mathrm{~m}(3 \mathrm{ft})$ \\
\hline 9 & $1.52 \mathrm{~m} \mathrm{(5 \textrm {ft } )}$ & $1.52 \mathrm{~m}(5 \mathrm{ft})$ & $1.52 \mathrm{~m}(5 \mathrm{ft})$ \\
\hline 10 & $2.44 \mathrm{~m}(8 \mathrm{ft})$ & Closed & Closed \\
\hline 11 & $2.44 \mathrm{~m}(8 \mathrm{ft})$ & $0.91 \mathrm{~m}(3 \mathrm{ft})$ & Closed \\
\hline 12 & $2.44 \mathrm{~m}(8 \mathrm{ft})$ & $0.91 \mathrm{~m}(3 \mathrm{ft})$ & $0.91 \mathrm{~m}(3 \mathrm{ft})$ \\
\hline 13 & $2.44 \mathrm{~m}(8 \mathrm{ft})$ & $1.52 \mathrm{~m}(5 \mathrm{ft})$ & Closed \\
\hline 14 & $2.44 \mathrm{~m}(8 \mathrm{ft})$ & $1.52 \mathrm{~m}(5 \mathrm{ft})$ & $0.91 \mathrm{~m}(3 \mathrm{ft})$ \\
\hline 15 & $2.44 \mathrm{~m}(8 \mathrm{ft})$ & $1.52 \mathrm{~m}(5 \mathrm{ft})$ & $1.52 \mathrm{~m}(5 \mathrm{ft})$ \\
\hline 16 & $2.44 \mathrm{~m}(8 \mathrm{ft})$ & $2.44 \mathrm{~m}(8 \mathrm{ft})$ & Closed \\
\hline 17 & $2.44 \mathrm{~m}(8 \mathrm{ft})$ & $2.44 \mathrm{~m}(8 \mathrm{ft})$ & $0.91 \mathrm{~m}(3 \mathrm{ft})$ \\
\hline 18 & $2.44 \mathrm{~m}(8 \mathrm{ft})$ & $2.44 \mathrm{~m}(8 \mathrm{ft})$ & $1.52 \mathrm{~m}(5 \mathrm{ft})$ \\
\hline 19 & $2.44 \mathrm{~m}(8 \mathrm{ft})$ & $2.44 \mathrm{~m}(8 \mathrm{ft})$ & $2.44 \mathrm{~m}(8 \mathrm{ft})$ \\
\hline
\end{tabular}

Size of each of gate is $1,22 \mathrm{~m} \times 2.44 \mathrm{~m}(4 \mathrm{ft} \times 8 \mathrm{ft})$ 
The main fish species that is observed in the dam-lake is smallmouth bass. Other fish species observed are largemouth bass, catfish, crappie, and perch. Smallmouth bass during its adult life stage was considered in this study. Of many habitat variables two important hydraulic variables, velocity and depth were considered in this study to calculate the fish habitat, i.e., WUA. The habitat suitability indices (HSI) for velocity and depth were obtained from Edwards et al. (1983) and are depicted in Fig. 4. The HSI shown in Fig. 4 are independent from each other, i.e., HSI for velocity and depth were calculated separately for each hydraulic attributes, i.e., for velocity and depth, and then the composite HSI was calculated from them. Please note that HSI for velocity is shown on the primary axis and HSI for depth is shown on the secondary axis.

The objective of this study was to maximize the total WUA over the entire simulation period. Please note that the difference between WUA which is perpendicular to the flow and the dam-lake surface area. The dam-lake surface area is the extent of the lake, and thus, it can be considered as parallel to the flow. The total WUA is calculated by summing up the WUA for the entire stream and for the 15-day long dam-lake operation period. The convergence of the objective function (total WUA) by each generation of the optimization search is shown in Fig. 5. At the first generation, the best objective function, i.e., the total WUA for the entire simulation period, was $33.91 \times 10^{6} \mathrm{~m}^{2}$ $\left(365 \times 10^{6} \mathrm{ft}^{2}\right)$ which converged to $41.81 \times 10^{6} \mathrm{~m}^{2}\left(450 \times 10^{6} \mathrm{ft}^{2}\right)$ at the $33 \mathrm{rd}$ generation. From generation 33 to 38 the objective function did not change, and therefore, the model stopped at the 38th generation. It is possible to rerun the model with different optimization parameters to check if the model converges at different or better objective functions. However, the purpose of this study is to demonstrate the development of a model that can successfully optimize the dam-lake operation to maximize fish habitat.

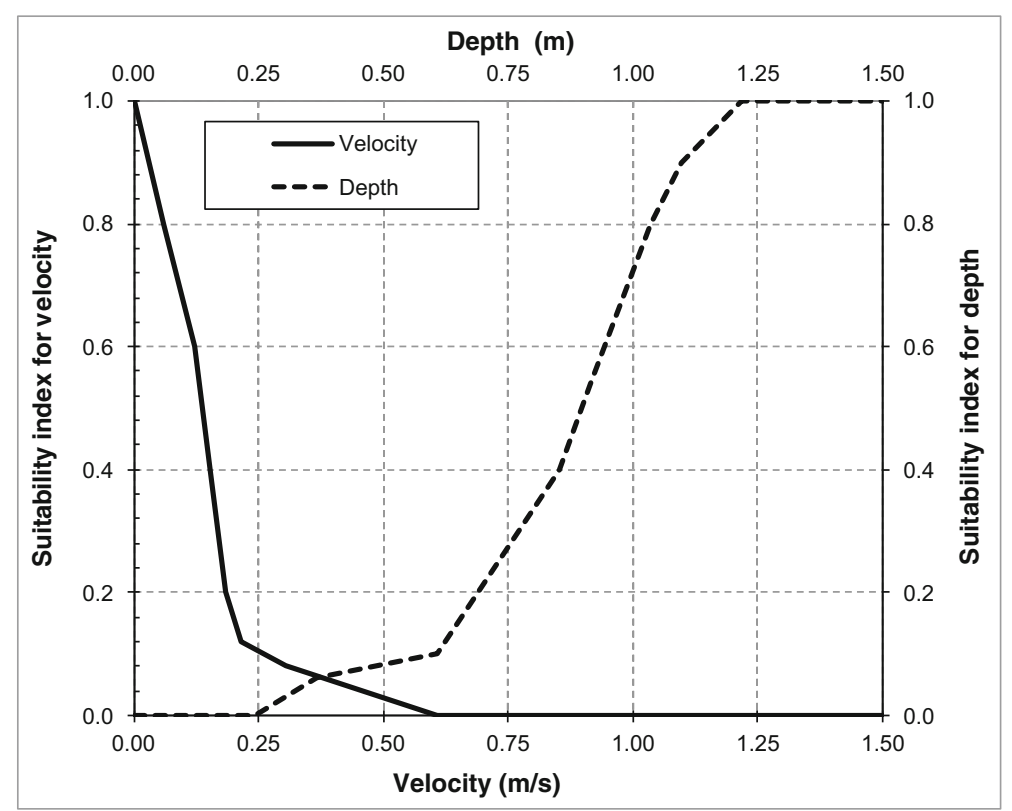

Fig. 4 Habitat Suitability Index (HSI) for velocity and depth for adult smallmouth bass (Edwards et al. 1983). HSI for velocity is on primary axes and HSI for depth is on secondary axes. They should be read separately 


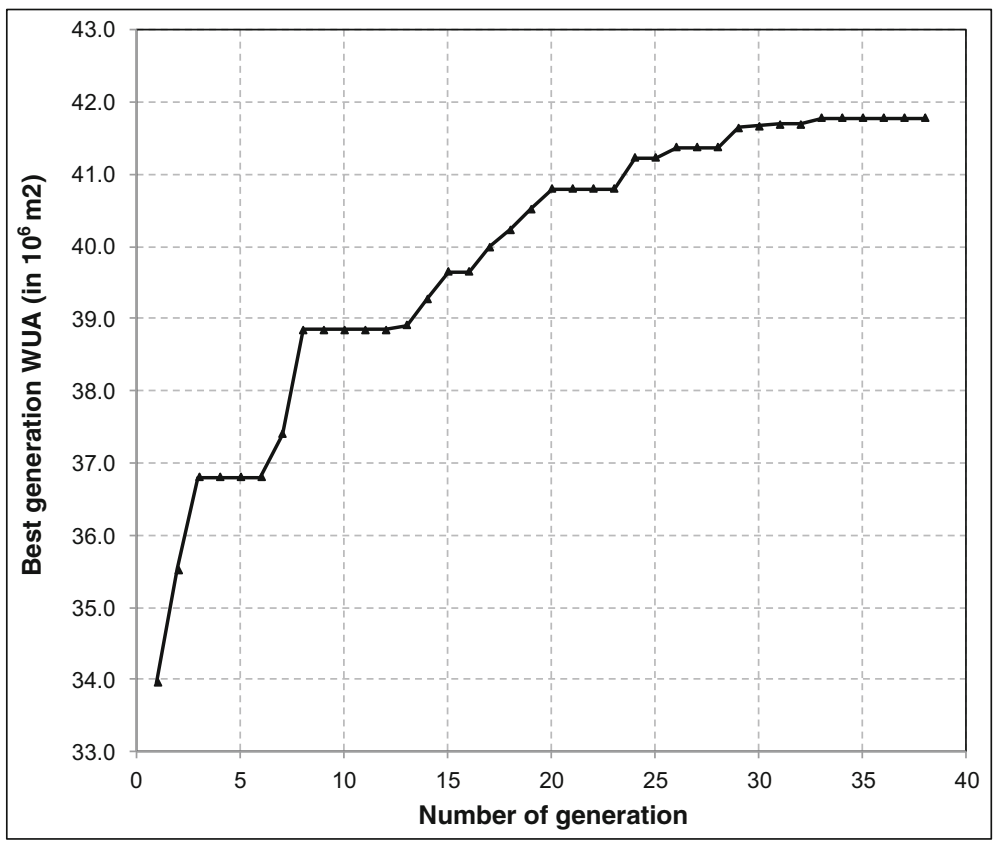

Fig. 5 Convergence of objective function (total WUA for entire simulation period)

The effect of water surface elevation in the dam-lake on daily WUA of the adult life stage of smallmouth bass is depicted by a scatter plot in Fig. 6. The relationship is somewhat nonlinear upward, i.e., WUA increases nonlinearly as the water surface elevation increases. The relationship agrees with the HSI curve for water depth (Fig. 4). HSI increases from 0.0 to

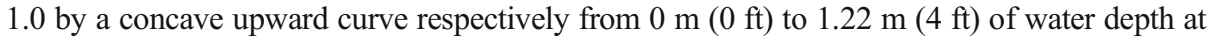
each transect. The HSI is 1.0 when the water depth is greater than $1.22 \mathrm{~m}(4.0 \mathrm{ft})$. Therefore, when the dam-lake water surface elevation is higher, it causes the water depth to be higher at each transect, resulting in higher HSI values and higher WUA.

As a result of the higher water surface elevation in the dam-lake, the extent of the damlake increases which reduces the velocity in the streams. Please note that if the dam-lake control gates are closed, the rate of increase in lake water surface elevation is extremely low compared to the water velocity in upstream channels that bring water in the lake. Therefore, the rate of change of water surface elevation in the lake can be assumed to be negligible, and thus, it provides higher HSI as a result of higher water surface elevation. Since the backwater effect is more prominent at higher water surface elevation in the lake, it affects in-stream hydraulics resulting in lower velocity in the streams. Consequently, the HSI values for velocity increases as the velocity decreases. Since the HSI values for velocity and depth are considered separately, if the velocity is greater than $0.61 \mathrm{~m} / \mathrm{s}(2.0 \mathrm{ft} /$ $\mathrm{s})$, the HSI value for velocity was taken as zero and if the velocity was $0 \mathrm{~m} / \mathrm{s}$ the HSI value was taken 1.0 . If the velocity was in between $0.61 \mathrm{~m} / \mathrm{s}(2 / \mathrm{ft} / \mathrm{s})$ and $0 \mathrm{~m} / \mathrm{s}$, the HSI value was determined per Fig. 4 (from primary vertical and horizontal axes). As a result, the HSI value is higher when the dam-lake water surface elevation increases. Therefore, with the increase of water surface elevation in the dam-lake, the extent of the dam-lake increases resulting in higher HSI values which cause higher WUA. 


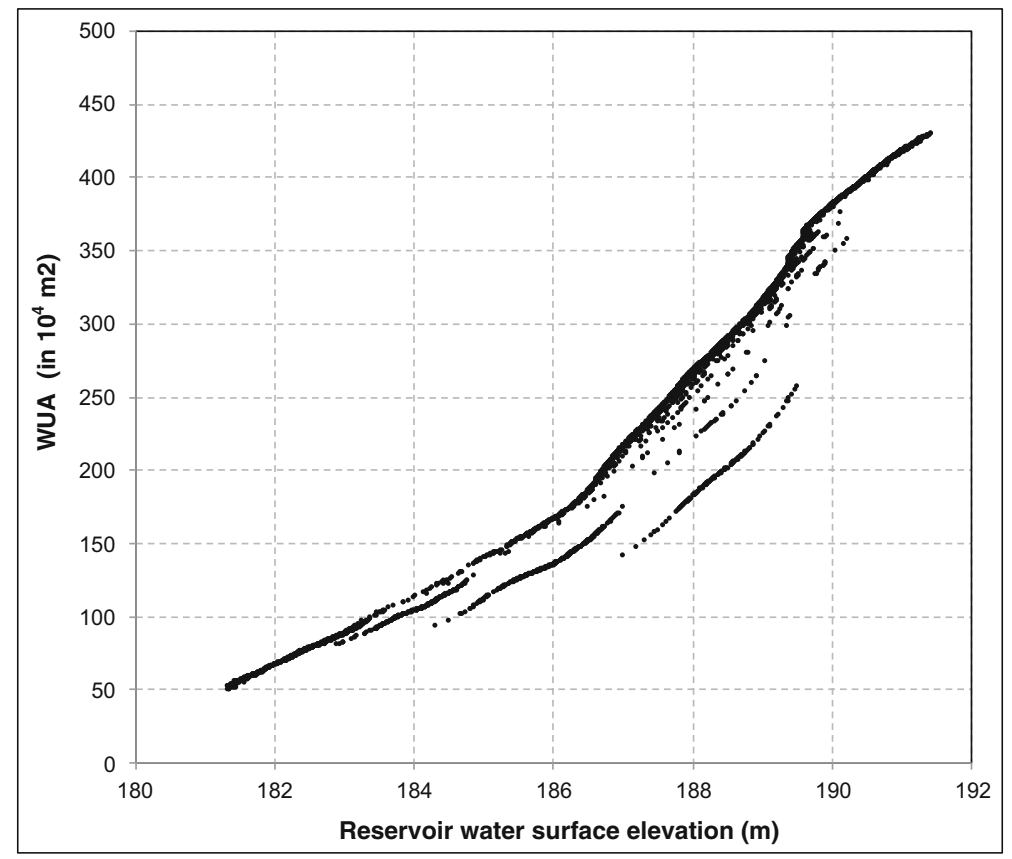

Fig. 6 Scatter plot of reservoir water surface elevation versus daily WUA

The effect of dam-lake outflow on daily WUA is shown on a scatter plot in Fig. 7. As seen, the WUA increases as the outflow increases following some distinct nonlinear patterns. Damlake outflow is controlled by rating curves. With three gates and defined openings the total possible gate configurations (hence rating curves) were 20 (Table 1). The dam-lake operation control rule is based upon the assumption that at least one gate is open during the simulation period to provide the minimum ecological and environmental flow. Please note that the purpose of this study is to develop a general optimization model and also the minimum ecological flow can vary from ecological region to region. Therefore, to develop a general optimization model any minimum flow would serve the purpose which can be satisfied by having at least one gate open during the entire simulation period. As a result, the option of all the gates closed was not considered in this optimization model. For a particular rating curve (gate configuration), the outflow increases as the water surface elevation increases. Alternatively, a higher water surface elevation also increases the WUA. When the optimization results are plotted in Fig. 7, it automatically shows 15 different distinct lines which represent different gate configurations used in the model. Four gate configurations were not optimal, and hence, they were automatically discarded by the optimization algorithm. Figure 8 shows gate openings and configurations during the dam-lake operation period for the best objective value $\left(\right.$ WUA $=41.81 \times 10^{6} \mathrm{~m}^{2}$ or $450 \times 10^{6} \mathrm{ft}^{2}$ ). As discussed earlier, the WUA increases as the water surface elevation in the dam-lake increases. Gate configuration 1 (Table 1) has the least

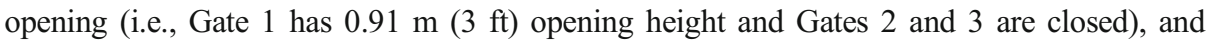
therefore, using this configuration will result in a higher water surface elevation in the damlake. As a result this configuration is found to be dominant in the optimal scenario.

Hydropower is a function of flow and hydraulic head. Higher water surface elevation in the dam-lake results in an increase in the hydraulic head which can help to generate 


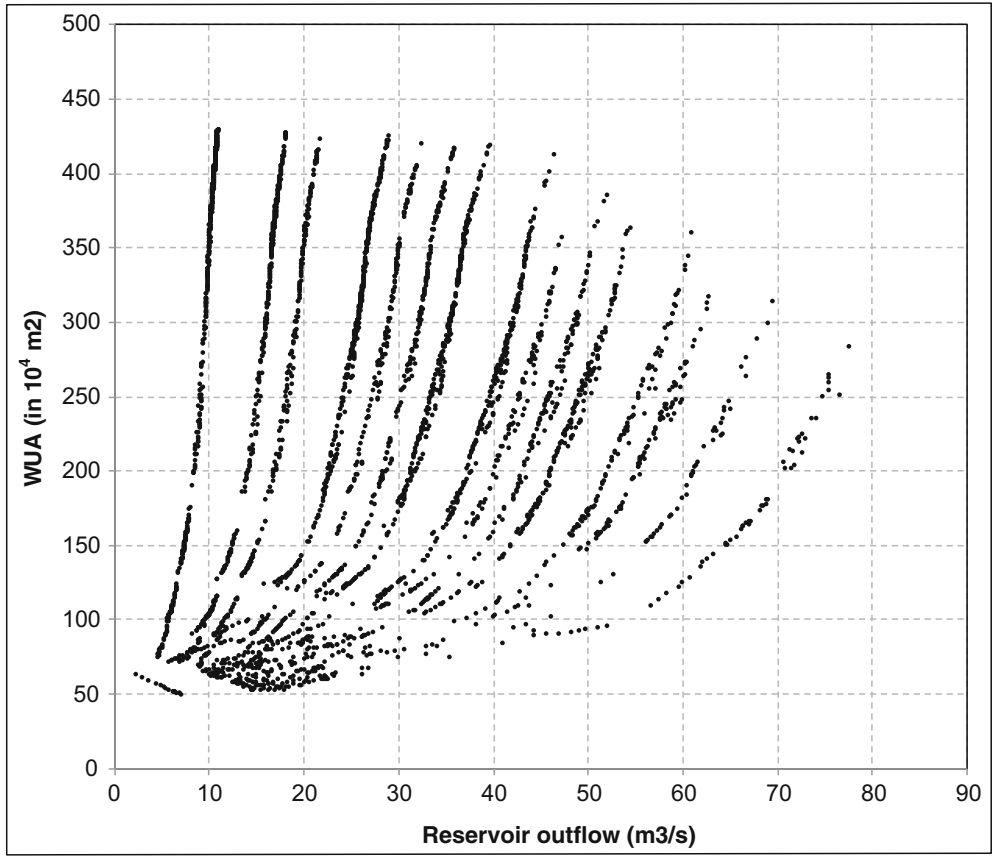

Fig. 7 Scatter plot of reservoir outflow versus daily WUA

more hydropower. The optimal dam-lake operation for maximizing fish habitat (for smallmouth bass in this study), thus can help to maximize hydropower generation as

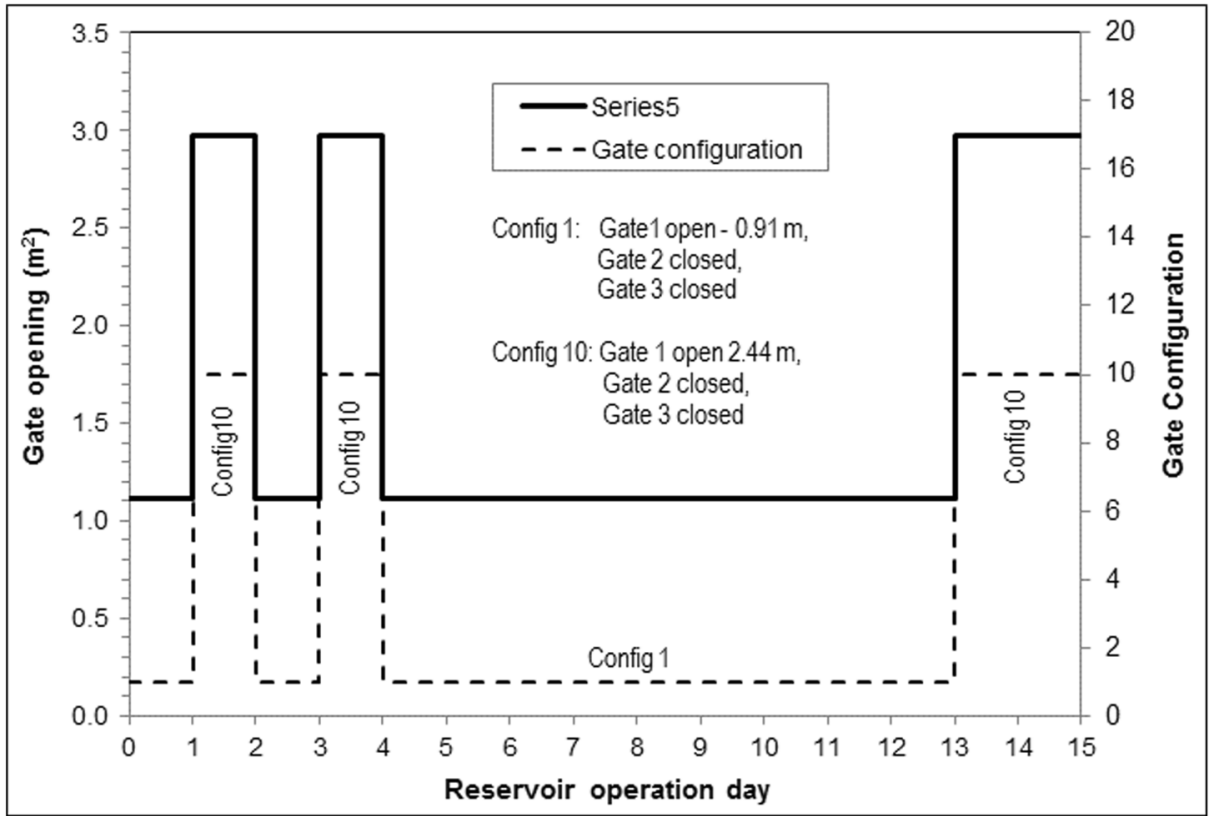

Fig. 8 Gate configuration and opening during reservoir operation 
well. However, other fish species with their different life stages and other ecological components should be considered simultaneously to check whether the increase of water surface elevation always increases the total WUA and is thus recommended for future study. For example, smallmouth bass which is considered to be a game fish in an ecological region can be a predator on juvenile salmon. Therefore, a tradeoff or proper weights must be considered in the optimization model. It is always recommended to maintain a minimum instream flow for the quality and quantity of aquatic habitat and environmental needs both upstream and downstream of the dam. Please note that the constraint of minimum water release from the dam should be considered explicitly as a function of environmental and ecological needs but not function of inflow to the dam-lake. As long as the minimum amount of water release criteria is met, the release can be function of inflow to the dam to determine the optimal dam-lake operation scenario. Since this study presents a general optimization methodology to maximize fish habitat, it provides a framework for a future study to consider all of these scenarios comprehensively.

\section{Conclusions}

A methodology to develop a dam-lake operation model to maximize the physical habitat of a fish species has been presented. Fish habitat is function of habitat suitability index and some hydraulics parameters. Hydraulics parameters are obtained from the simulation of an onedimensional hydraulics model, HEC-2. The dam-lake water surface elevation, storage, and release (outflow) are obtained using the dam-lake simulation model, HEC-5. The entirety of the operation model has been developed by linking HEC-2 and HEC-5 with a meta-heuristic optimization algorithm, the Shuffled Frog Leaping Algorithm. The objective function of the optimization algorithm is fish habitat which is coded within the optimization algorithm. The operation model has been successfully applied to an unnamed dam-lake in the northeast of the U.S. to maximize the physical habitat of smallmouth bass in its adult life stage. For smallmouth bass in its adult life stage, the habitat suitability index is inversely proportional to the velocity and directly proportional to the depth. As a result, the fish habitat increases as the water surface in the dam-lake increases.

The model can be improved by considering multiple purposes of the dam-lake operation. These multiple purposes can be either included in the objective function or can be considered as constraints. For example, environmental or ecological flow at the downstream of the damlake, total dissolved gas (TDG) or level of oxygen in dam-lake water, residence time of damlake water, etc., can be considered as the constraints. Hydropower generation can be maximized if water surface elevation in the dam-lake increases or the outflow (release) increases. Hydropower generation can be considered in the objective function.

For a constant inflow, since both the release and the water surface elevation in the dam-lake cannot be maximized at the same time, the dam-lake operation for hydropower generation requires further study on how to maximize the revenue or power generation. In this case, the peak time and off-peak time of electricity tariff play an important role. Similarly, there may be one fish in its particular life stage which requires lower in-stream depth of water while another fish species may require a higher depth. The impacts of dam-lake operation on the physical habitat of multiple fish species in their multiple life stages require in-depth investigation. Other usages of dam-lake such as water supplies for agriculture, domestic, industry, and recreation can also be included in the dam-lake operation model. 
Acknowledgments The authors would like to acknowledge the suggestions, explanations, and advices made by Dr. Terry J. Waddle, Hydrologist, U.S. Geological Survey, Fort Collins Science Center. Authors also appreciate all reviewers' comments to improve the quality of the work.

\section{References}

Bunn SE, Arthington AH (2002) Basic principles and consequences of altered hydrological regimes for aquatic biodiversity. Environ Manag 30:492-507

Chen D, Li R, Chen Q, Cai D (2015) Deriving optimal daily reservoir operation scheme with consideration of downstream ecological hydrograph through a time-nested approach. Water Resour Manag: 1-16. doi: 10. 1007/s11269-015-1005-z

Conder AL, Annear TC (1987) Test of weighted usable area estimates derived from a PHABSIM Model for Instream flow studies on trout streams. N Am J Fish Manag 7(3):339-350

Duke S, Anders P, Ennis G, Hallock R, Hammond J, Ireland S, Laufle J, Lauzier R, Lockhard L, Marotz B (1999) Recovery plan for Kootenai River white sturgeon (Acipenser transmontanus). J Appl Ichthyol 15(4-5):157163

Edwards EA, Gebhart G, Maughan OE (1983) Habitat suitability information: Smallmouth bass. U.S. Dept. Int., Fish Wildl. Serv. FWS/OBS-82/10.36: 47 pp

Eusuff M, Lansey K, Pasha F (2006) Shuffled frog-leaping algorithm: a memetic meta-heuristic for discrete optimization. J Eng Optim 38(2):129-154

FOEN (Federal Office for Environment) (2013) Hydropeaking. http://www.bafu.admin.ch/gewaesserschutz/ 04851/index.html?lang=en. Accessed 5 June 2013

Heath MW, Wood SA, Brasell KA, Young RG, Ryan KG (2015) Development of habitat suitability criteria and in-stream habitat assessment for the benthic cyanobacteria phormidium. River Res Appl 31(1):98-108

Jager HI, Smith BT (2008) Sustainable reservoir operation: can we generate hydropower and preserve ecosystem values. River Res Appl 24:340-352

King AJ, Gawne B, Beesley L, Koehn JD, Nielsen DL, Price P (2015) Improving ecological response monitoring of environmental flows. Environ Manag 55:991-1005. doi:10.1007/s00267-015-0456-6

Lauters F, Lavandier P, Lim P, Sabaton C, Belaud A (1996) Influence of hydropeaking on invertebrates and their relationship with fish feeding habits in a Pyrenean river. Regul Rivers Res Manag 12(6):563-573

Liebig H, Cereghino R, Lim P, Belaud A, Lek S (1999) Impact of hydropeaking on the abundance of juvenile brown trout in a Pyrenean stream. Arch Hydrobiol 144(4):439-454

Liu Y, Yang W, Yu Z, Lung I, Yarotski J, Elliott J, Tiessen K (2014) Assessing effects of small dams on stream flow and water quality in an agricultural watershed. J Hydrol Eng 19(10):05014015

McDonald R, Nelson J, Paragamian V, Barton G (2010) Modeling the effect of flow and sediment transport on white sturgeon spawning habitat in the Kootenai River, Idaho. J Hydraul Eng 136(12):1077-1092

National Fish Habitat Action Plan (2009) Conserving healthy reservoir systems - A framework for strategic conservation of fish habitat in the reservoir systems of the United States. Partners of the reservoir fisheries habitat partnership candidate fish habitat partnership

Null SE, Lund J (2012) Fish habitat optimization to prioritize river restoration decisions. River Res Appl 28(9): 1378-1393

Orth D, Diplas P, Dolloff C, Newcomb T, Krause C, Novinger D, Anderson M, Buhyoff G, Hunter A, Shen Y (2004) Influences of fluctuating releases on stream fishes in the Smith River below Philpott Dam: Final Report. Virginia Polytechnic Institute and State University, Blacksburg, VA. Contract 8220203: 284

Paragamian VL, Kruse G, Wakkinen V (2001) Spawning habitat of Kootenai River white sturgeon, post-Libby Dam. N Am J Fish Manag 21(1):22-33

Pasha MFK, Lansey K (2009) Water quality parameter estimation for water distribution systems. J Civil Eng Environ Syst 26(3):231-248

Payne T R (2003) The Concept of Weighted Usable Area as Relative Suitability Index. IFIM Users Workshop 15 June 2003 Fort Collins, CO

Piman T, Cochrane T, Arias M, Green A, Dat N (2013) Assessment of flow changes from hydropower development and operations in sekong, sesan, and Srepok Rivers of the Mekong Basin. J Water Resour Plan Manag 139(6):723-732

Poff NL, Allan JD, Bain MB, Karr JR, Prestegaard KL, Richter BD, Sparks RE, Stromberg JC (1997) The natural flow regime: a paradigm for river conservation and restoration. Bioscience 47:769-784

Postel S, Richter B (2003) Rivers for life: managing water for people and nature. Island Press, Washington, DC 
Raleigh R F, Zuckerman L D, Nelson P C (1986) Habitat suitability index models and instream flow suitability curves: Brown trout, revised. U.S. Fish Wildl. Servo Biol. Rep. 82(10.124):65 pp. [First printed]

Richter B D, Thomas G A (2007) Restoring environmental flows by modifying dam operations. Ecology and Society 12(1):12. [online] URL: http://www.ecologyandsociety.org/vol12/iss1/art12/

Setter A, Brannon E (1990) Report on Kootenai River white sturgeon electrophoretic studies - 1989. Report for the Idaho Department of Fish and Game. Aquaculture Extension, Univ. of Idaho:30-50 pp. Kootenai River White Sturgeon Investigations and Experimental Culture. Annual Progress Rep. No. FY 1989, K. A. Apperson, ed., Idaho Dept. of Fish and Game and Bonneville Power Administration, Portland, Ore., Contract No. DE-A179-88BP3497, Project No. 88-65.

Shen Y, Diplas P (2010) Modeling unsteady flow characteristics of hydropeaking operations and their implications on fish habitat. J Hydraul Eng 136(12):1053-1066

Simon TP, Cooper NJ (2014) Habitat Suitability Index Relationships for the Northern Clearwater Crayfish, Orconectes Propinquus, (Decapoda: Cambaridae). Fish Aquac J 5:098. doi:10.4172/2150-3508.100098

USACE (U.S. Army Corps of Engineers) (1991) User's Manual, HEC-2, Water Surface Profiles. Hydrologic Engineering Center, Davis, CA 95616

USACE (U.S. Army Corps of Engineers) (1998) User's Manual, HEC-5, Simulation of Flood Control and Conservation Systems. Hydrologic Engineering Center, Davis, CA 95616

USFWS (U.S. Fish and Wildlife Service) (1994) Endangered and threatened wildlife and plants; determination of endangered status for the Kootenai River population of white sturgeon-Final rule. Fed Regist 59171: 45989-46002

Waters MN, Golladay SW, Patrick CH, Smoak JM, Shivers SD (2015) The potential effects of river regulation and watershed land use on sediment characteristics and lake primary producers in a large reservoir. Hydrobiologia 749:15-30

Yao W, Rutschmann P, Bamal S (2014) Modeling of river velocity, temperature, bed deformation and its effects on rainbow trout (Oncorhynchus mykiss) habitat in Lees Ferry, Colorado River. Int J Environ Res 8(4):887896 